This is an electronic reprint of the original article. This reprint may differ from the original in pagination and typographic detail.

Please cite the original version: Luojus, S. Kauppinen, S. \& Tossavainen, P. (2021) Framework for Assessing Pedagogical Solutions: Experiences in Laurea's Master's Degree Programme in Service Design. INTED2021 Proceedings, pp. 5514-5520. 


\title{
FRAMEWORK FOR ASSESSING PEDAGOGICAL SOLUTIONS: EXPERIENCES IN LAUREA'S MASTER'S DEGREE PROGRAMME IN SERVICE DESIGN
}

\author{
Satu Luojus, Sami Kauppinen, Päivi Tossavainen \\ Laurea University of Applied Sciences (FINLAND)
}

\begin{abstract}
In the service business environment, new kinds of expertise in the development and management of services and service business are needed. New competence needs related to work have challenged higher education institutions that offer service business and service design to develop new types of pedagogical solutions. Laurea University of Applied Sciences is one of the first higher education institutions to offer EQF7 (European Qualifications Framework, level 7) level service design studies. At present, Laurea University of Applied Sciences (Laurea) has three degree programmes leading to a Master's degree in which service design is approached from the theoretical perspectives of marketing and management of services. The programmes are intended for those working in management, expert or development positions, and who want to become forward-looking service innovators.

The purpose of this article is to deepen the understanding of pedagogical solutions for the EQF7-level studies in service design offered by Laurea. The theoretical starting point is the Trialogical epistemology of innovative knowledge communities developed by Paavola and Hakkarainen [1]. Trialogical approach refers to learning as a process of knowledge creation, which focuses on mediated processes where shared objects of activity are developed collaboratively. This approach promotes to elicit and helps to understand the processes of knowledge advancement that are essential to an advanced knowledge society.

In this article, we assess the pedagogical solutions of the three study units of service design in the theoretical framework by comparing them against three metaphors of learning. The three metaphors of learning (monological, dialogical and trialogical) provide a valuable framework for evaluating pedagogical solutions. The results indicate that the learning process of an innovative knowledge community should consist of all three pedagogical solutions that support the different metaphors of learning.
\end{abstract}

Keywords: assessing pedagogical solutions, higher education, knowledge-creation, innovative knowledge communities, Trialogical approach.

\section{INTRODUCTION}

Over 60 per cent $(61.2 \%)$ of the world's GDP consisted of services [2]. At the same time, services accounted for more than two thirds $(69.4 \%)$ of the value of Finland's gross domestic product [3]. Four out of five jobs in the Helsinki Metropolitan area are in services, which is typical for an advanced information society [4]. The importance of services is still increasing, and emphasize the significance of service innovations. This is why a new kind of development and management competence in services and service business is needed in the service business environment. New competence needs related to work have challenged higher education institutions that offer service business and service design to develop new types of pedagogical solutions.

Laurea University of Applied Sciences (Laurea) is profiled as a higher education institution with a focus on regional development. Laurea's aim is to be an international developer of working life competence and vitality in Uusimaa region in Finland. Laurea's strengths include service design and co-creation, comprehensive security, competence that renews the social and health sector, and ethical competence and management. Laurea is one of the first higher education institutions to offer EQF7 (European Qualifications Framework, level 7) service design studies since 2007. At present, Laurea has three Master's degree programmes - Service Design, Service Design and Innovation and Innovative Digital Services in the Future - that approach service design from the theoretical perspectives of marketing and management of services. The degrees are intended for those working in management, expert or development positions, and who want to become forward-looking service innovators. The degree programmes apply new thinking models and design thinking in service 
business in the context of innovation activities, management and service development. The purpose of this article is to deepen the understanding of pedagogical solutions for the EQF7-level studies in service design offered by Laurea.

\section{A KNOWLEDGE-CREATION METAPHOR OF LEARNING}

Paavola and Hakkarainen [5] argue that in addition to the traditional metaphors of learning; the acquisition metaphor (a "monological" approach), and the participation metaphor (a "dialogical" approach), there is also a third "trialogical" approach. The knowledge-acquisition metaphor relies on the idea that knowledge is a property or characteristic of an individual mind. An individual is seen as the basic unit of learning, and learning as a process of transferring information to the individual agent. The acquisition metaphor emphasizes propositional knowledge and conceptual knowledge structures. According to the participation metaphor of learning, "learning is an interactive process of participating in various cultural practices and shared learning activities that structure and shape cognitive activity in many ways, rather than something that happens inside individuals' minds" [6]. Learning is regarded "as a process of becoming a member of a community and acquiring the skills to communicate and act according to its socially negotiated norms". The participation metaphor focuses more on activities (i.e. "knowing") than on outcomes. Paavola and Hakkarainen [5] regards the division of two basic metaphors of learning fundamental, but not sufficient when "addressing processes of deliberately creating and advancing knowledge".

The Trialogical epistemology of innovative knowledge communities by Paavola and Hakkarainen [1] is based on different models and theories of learning and human activities that emphasise "mediation" and "knowledge-creation". Grounded on theories of innovative knowledge communities they present a knowledge-creation metaphor of learning [5]. The models of knowledge-creation emphasise the idea that learning is not only individual acquisition of knowledge (mental monology), but not just cultural participation either (dialogue in a social community); it is also a "trialogical" activity that refers to communal, long-term, targeted work to create and develop some shared objects (ideas, concrete products) [7]. In other words, trialogy refers to the formation and development of a shared object in innovative knowledge communities, which takes place in a communal manner and in which various intermediate tools, processes, signals and artefacts (conceptual and material) are used [1]. The monological, dialogical [8] and trialogical approaches are based on the three metaphors of learning (Figure 1), which approach learning as: a) information acquisition, b) cultural participation and c) knowledge-creation. [7].

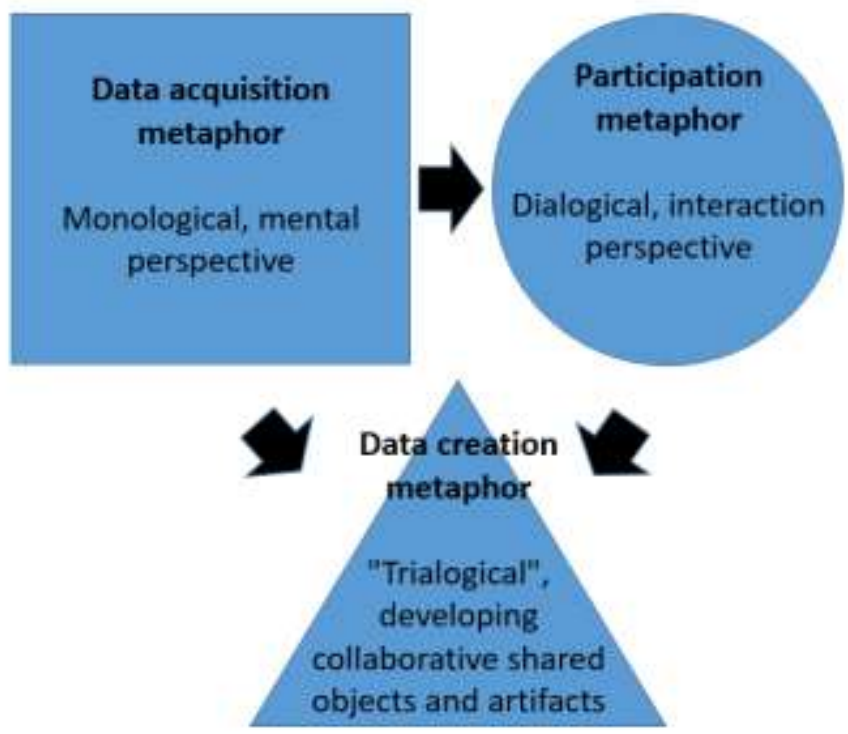

Figure 1. The three metaphors of learning [7]

The knowledge-creation metaphor refers to learning as a process of knowledge-creation which focuses on mediated processes where shared objects of activity are developed collaboratively. 
Trialogical approach emphasises the idea that learning is not only individual acquisition of knowledge (mental monology), but not just cultural participation either (dialogue in a social community); it is also a "trialogical" activity that refers to shared, long-term, targeted work to create and develop some shared objects (ideas, concrete products). [7]. A trialogical approach can be seen as conscious and systematic co-creation and production of new knowledge. For this reason, it is very compatible with the learning model "Learning by developing"' (LbD) by Laurea [9].

Information is created by organising a social community to work together with mediation tools to develop students shared goals [1]. By trialogical learning, Paavola [10] refers to a form of communal learning in which activities are organized around the development of shared objects that are created and modified together. Shared objects can be different artefacts, such as texts, templates, plans, services, or products. The basic idea of trialogical learning is that in addition to purely individual learning or pure social interaction, the emphasis is on concrete outputs that are together modified for further use [10]. The following six key principles of trialogical learning guide the planning of teaching and assessing pedagogical solutions:

1 Organizing activities around shared objects. The starting point for planning is the shared target of development for the students, which may be a product or service to be developed for the client as a learning assignment.

2 Supporting interaction and agency between personal and social levels. Students take responsibility not only for their own learning, but also for the collaborative process and its outputs that combine the students' personal competences and objectives as well as shared goals.

3 Fostering long-term processes of knowledge advancement. The target of collaborative development must have further use after a single study unit. In general, the aim is to find continuity between different learning situations.

4 Development through supporting interaction and reflection between various forms of knowledge (silent information, practices, conceptualization) The aim is to promote the integration of practical information into conceptualization, reflection and documentation in different forms.

5 "Cross-fertilization" of various knowledge practices across contexts and communities. The aim is to ensure that collaborative development takes place in an authentic development environment, involving students as well as the customer and other stakeholders of the development task.

6 Providing flexible tools to support trialogical learning. [1, 10].

Trialogical learning has been applied especially to the implementation of extensive and demanding study modules in higher education institutions. In these modules, students are tasked to take a lot of responsibility for organising the entire development process, its outcomes and keeping in contact with the client [10] as well as other stakeholders.

\section{METHODOLOGY}

Our case study examines the objectives, implementation and pedagogical solutions of three separate cases, i.e. Master's degree courses. The research material consists of the course documentation, such as implementation plans, learning exercises, observation, evaluation and teacher's notes. We analyse the pedagogical solutions of these three in the framework of the theory of knowledge building, reflecting on them based on the three metaphors of learning: monological, dialogical and trialogical (Table 1).

The first one is the complementary course 'Competence in service design' (5 ETCS). It is intended for students in other Master's degree programmes, whose core studies do not include studies in service design. The purpose of the course is therefore to familiarize students in different fields with the basic concepts and ideas of service design. The aim is that after completing the study unit, the student is able to: a) understand the theoretical perspective of service thinking and the connection with service design as well as design thinking on the background of service design; b) assess the possibilities of service design in the development work of their own field; c) synthesize the basic concepts, processes and key methods of service design; d) apply the service design approach and tools in service development; e) analyze their own competence and assess the significance of different roles and skills in co-creation; and f) obtain, process, produce and critically assess information about service design and apply it in practice in their own work. In addition to the preliminary assignment, the study unit 
includes three learning exercises that are assessed: a literature assignment based on the basic literature of service design and two writing assignments, the first of which is related to the service design process and familiarization with a tool, and the second is related to describing your own professional perspective. In addition, during the teaching sessions, the students familiarize themselves with the challenges of multiprofessional work in service design on the basis of the descriptions written above.

Table 1. Pedagogical solutions for study unit implementation in the framework of theory of knowledge building

\begin{tabular}{|c|c|c|c|}
\hline Study unit & Monological learning & Dialogical learning & Trialogical learning \\
\hline $\begin{array}{l}\text { Competence in } \\
\text { service design } \\
5 \text { ETCS }\end{array}$ & $\begin{array}{l}\text { Individual assignments: } \\
\text { - Introduction to the principles of } \\
\text { service design } \\
\text { - Articles and essay (preliminary } \\
\text { assignment) } \\
\text { - Basic literature of service } \\
\text { design, articles and presentation } \\
\text { of the tool as well as describing } \\
\text { your own professional approach }\end{array}$ & $\begin{array}{l}\text { Group work: } \\
\text { - The challenges of } \\
\text { multiprofessional work in } \\
\text { service design are discussed in } \\
\text { small groups }\end{array}$ & \\
\hline $\begin{array}{l}\text { Service design } \\
\text { process and } \\
\text { methods } 10 \\
\text { ETCS }\end{array}$ & $\begin{array}{l}\text { Individual assignment: } \\
\text { - Getting to know the reading } \\
\text { circle literature and preparation of } \\
\text { introductions }\end{array}$ & $\begin{array}{l}\text { Group work: } \\
\text { - Reading circle meetings to } \\
\text { discuss literature in small } \\
\text { multidisciplinary groups } \\
\text { - Determining the objectives of } \\
\text { the service design project and } \\
\text { preparing a project plan in } \\
\text { small multidisciplinary groups } \\
\end{array}$ & $\begin{array}{l}\text { Group work: } \\
\text { - Completing a service } \\
\text { design project to develop } \\
\text { a service concept in } \\
\text { small multidisciplinary } \\
\text { groups }\end{array}$ \\
\hline $\begin{array}{l}\text { Agile methods } \\
\text { in service } \\
\text { design } 10 \\
\text { ETCS }\end{array}$ & $\begin{array}{l}\text { Individual assignment: } \\
\text { - Literature review and an essay } \\
\text { based on it }\end{array}$ & $\begin{array}{l}\text { Group work: } \\
\text { - Small multidisciplinary groups } \\
\text { reflect on the agile } \\
\text { development project they have } \\
\text { implemented in context of the } \\
\text { literature }\end{array}$ & $\begin{array}{l}\text { Group work: } \\
\text { - Completing an agile } \\
\text { development project to } \\
\text { develop a service } \\
\text { concept in small } \\
\text { multidisciplinary groups }\end{array}$ \\
\hline
\end{tabular}

The second module consists of the core studies of the Service Design and Innovative Digital Services in the Future degree programmes. 'Service design process and methods' is 10 ETCS. The aim is that after having completed the study unit, the student is able to: a) apply the principles of service logic in the development of service business and digital services; b) assess and apply the methods and techniques of service design in a diverse manner in the different phases of the development of digital services and the service ecosystem; c) understand the communicative and experimental nature of design; d) steer and analyze the shared process of information acquisition and material collection in co-creation workshops; e) independently plan, facilitate and implement inclusive workshops, analyze the material collected in workshops and report the results of data acquisition; and f) consider the ethical questions of co-creation.

The study unit includes two extensive, demanding and assessed learning exercises: a reading circle assignment and a service design project for a client. The purpose of collaborative work and peer learning in the reading circle assignment is to open new perspectives in the development of services. The knowledge base of the service design project exercise is based on reading circle literature among other materials, and the information adopted can be used to justify the choices made in the development exercise (development process, methods). The service design project assignment develops an existing or completely new service in accordance with the selected service design process model. The methods and tools of service design are used for the development. The end result of the assignment is a service concept developed for the client which has been tested using prototyping. The student writes a report on the work and presents it. The final report describes the implementation of the development assignment (project progress) and its results (developed service concept).

The third study unit examined is the complementary study unit 'Agile methods in service design' (10 ETCS). It is intended as a complementary competence for students of Laurea's Finnish-speaking 
Master's degree programmes, who have already completed some service design studies. The aim is that after completing the study unit, the student will be able to: a) plan and implement an agile design sprint and understand the benefits of the method; b) use service design methods and tools to identify design opportunities and implement service prototypes; c) outline and visualize alternative design solutions and evaluate them critically; and d) develop design solutions on the basis of user information in an agile and iterative manner. The study unit includes three demanding learning exercises that are evaluated: An essay based on a literature review, an agile development project and an essay on the development work based on course literature. The agile development project task develops an existing or entirely new service for a client. Agile development methods and tools are used in the development work. The end result of the assignment is a service concept developed and tested for the client. The development work carried out is reported, and it is reflected in the literature review based on the literature.

\section{RESULTS AND DISCUSSION}

Our aim was to deepen the understanding of pedagogical solutions for the EQF7-level studies in service design offered by Laurea. For this purpose, we examined the objectives, implementation and pedagogical solutions of the three Master's degrees. We analysed them in the framework of theory of knowledge building by comparing them with three metaphors of learning: monological, dialogical and trialogical. The assessment of pedagogical solutions showed that learning in higher education is much more than just the process of recording information within the human mind. As stated in the abovementioned literature, it also involves a large number of communal processes and the development of shared, mutual objects that are not accessible for immediate observation.

The simple classification of pedagogical solutions in study units in accordance with the three metaphors of learning showed that courses whose objectives are related to the acquisition of basic knowledge and skills follow the monological and dialogical metaphors of learning. In these courses, learning was approached as information acquisition and participation in culture. Monological, mental and independent information acquisition and, on the other hand, dialogical, interactive sharing and participation were emphasised. It is therefore recommended to plan assignments for the study units that allow the student to reflect on and deepen their understanding of the new topic in interaction with other students. In this way, a mental perspective that the student has created themselves becomes more specific, deeper or changes in interaction with other students. The dialogue taking place in the student group in the social community strengthens the student's trust in fully comprehending the subject being studied. During the study unit on service design, competence was seen to improve in discussions during days of teaching. Independent orientation to the topic through literature needed confirmation from other actors, especially in the comprehension of sector-specific vocabulary, in-depth understanding of concepts and linking one's own professional competence to the topic being studied.

A separate assignment aiming at trialogy has not been included in the study unit, as the topic is quite challenging even in terms of understanding the criteria. After comprehending the basics of service design, the students are prepared to deepen their competence in service design and become more familiar with the culture of service design as part of their later Master's degree studies. According to our research, a combination of monological and dialogical learning can help achieve basic competence on the subject being studied.

In courses that deepen and expand competence, learning was also approached from the perspective of creating knowledge. In these courses, the shared target of creating and developing information was the real-life work assignment. The students took responsibility not only for their own learning but also for the shared (service design) project and its end result, i.e. the design of a new service concept. The project combines the students' personal competence and objectives as well as objectives defined together. The service concept that was the objective of mutual development was presented to the client, who utilised it in the development of their own business. Practical development work was naturally combined with the conceptualisation and reflection of the design challenge and the documentation of the development work. The development work was carried out in a real development environment, involving not only the client's representatives but also their customers. Different tools and aids (e.g. conceptual and methodological) supported learning. The implementation of the study periods thus followed the principles and planning principles of trialogical learning. The information creation approach and the shared work on the working life assignment, i.e. development of a shared object (co-creation), require a longer time span and a wider focus on the learning process. 
Table 2. Study unit planning and evaluation tool that utilizes the three metaphors of learning [11]

\begin{tabular}{|c|c|c|c|}
\hline & Monological learning & Dialogical learning & Trialogical perspective \\
\hline & $\begin{array}{l}\text { - Monological, i.e. mental } \\
\text { perspective } \\
\text { - Learning through data } \\
\text { acquisition } \\
\text { - Learning takes place in a } \\
\text { person's mind that } \\
\text { processes especially } \\
\text { conceptual knowledge } \\
\text { and concept structures } \\
\text { - The mind of an individual; } \\
\text { individual expertise; } \\
\text { - information processing } \\
\text { skills }\end{array}$ & $\begin{array}{l}\text { - Dialogical, i.e. interaction } \\
\text { perspective } \\
\text { - Learning through participation } \\
\text { in culture } \\
\text { - Learning emphasizes } \\
\text { communality and the process } \\
\text { of growing into a community } \\
\text { - Communal practices, cultural } \\
\text { information, operator networks }\end{array}$ & $\begin{array}{l}\text { - Trialogical, i.e. developing mutual } \\
\text { goals together } \\
\text { - Learning as knowledge creation } \\
\text { - The starting point of learning is not } \\
\text { just a human's mind or communal } \\
\text { practices in themselves, but the } \\
\text { interaction between the individual } \\
\text { and the community, which is seen to } \\
\text { take place through intermediate } \\
\text { artefacts produced by different } \\
\text { people. Special focus is on } \\
\text { processes in which something new } \\
\text { is produced communally } \\
\text { - A conscious and systematic effort to } \\
\text { develop socially shared objects } \\
\text { (material or conceptual artefacts) in } \\
\text { a communal way and to exceed } \\
\text { prior learning }\end{array}$ \\
\hline & - Activity unit: Individuals & $\begin{array}{l}\text { - Activity unit: Communities or } \\
\text { individuals } \\
\text { as a part of an operating } \\
\text { environment }\end{array}$ & $\begin{array}{l}\text { Activity unit: Interaction between } \\
\text { individuals and the community } \\
\text { through artefacts and tools }\end{array}$ \\
\hline $\begin{array}{l}\text { 1. Starting } \\
\text { points for } \\
\text { planning } \\
\text { the } \\
\text { learning } \\
\text { exercise }\end{array}$ & $\begin{array}{l}\text { - Each student has } \\
\text { competence based on } \\
\text { their previously acquired } \\
\text { educational background, } \\
\text { which will be expanded }\end{array}$ & $\begin{array}{l}\text { - Students are divided into } \\
\text { multiprofessional design } \\
\text { teams in which competence is } \\
\text { shared }\end{array}$ & $\begin{array}{l}\text { - Students are divided into } \\
\text { multiprofessional design teams in } \\
\text { which existing competence is } \\
\text { shared and new knowledge is } \\
\text { created through mutual } \\
\text { development of shared objects }\end{array}$ \\
\hline $\begin{array}{l}\text { 2. Defining } \\
\text { the } \\
\text { learning } \\
\text { exercise }\end{array}$ & $\begin{array}{l}\text { - Students familiarize } \\
\text { themselves with a } \\
\text { planned project } \\
\text { assignment and the } \\
\text { sector in question } \\
\text { independently } \\
\text { - Students deepen their } \\
\text { knowledge by } \\
\text { familiarizing themselves } \\
\text { with the key concepts and } \\
\text { theories of the study unit } \\
\text { - Students practice using } \\
\text { methods and tools } \\
\text { independently } \\
\end{array}$ & $\begin{array}{l}\text { - Students deepen their own } \\
\text { understanding by working } \\
\text { together and learning from } \\
\text { each other, e.g. by discussing } \\
\text { the key concepts and theories } \\
\text { of the study unit together } \\
\text { - Students use boundary } \\
\text { objects to communicate and } \\
\text { form a shared understanding } \\
\text { - Student groups practice the } \\
\text { use of methods and tools } \\
\text { together }\end{array}$ & $\begin{array}{l}\text { - Teachers, students and the client } \\
\text { work together to complete the } \\
\text { design challenge } \\
\text { - Multidisciplinary student groups } \\
\text { define the objective of their own } \\
\text { group work and make it a "socially } \\
\text { shared target of development" for } \\
\text { themselves } \\
\text { - Students from different backgrounds } \\
\text { share and develop their } \\
\text { competence and create new } \\
\text { knowledge to achieve a shared goal }\end{array}$ \\
\hline $\begin{array}{l}\text { 3. Completing } \\
\text { the } \\
\text { learning } \\
\text { exercise }\end{array}$ & $\begin{array}{l}\text { - Students complement } \\
\text { their skills as necessary; } \\
\text { expertise of the field, } \\
\text { concepts, theories, } \\
\text { methods and tools }\end{array}$ & $\begin{array}{l}\text { - The teacher guides the design } \\
\text { team and the completion of } \\
\text { the learning exercise } \\
\text { - Multidisciplinary teams share } \\
\text { their competence to complete } \\
\text { the learning exercise } \\
\text { - Teams use visualizations and } \\
\text { prototypes to support } \\
\text { discussion between the } \\
\text { teacher and client (i.e. use } \\
\text { boundary objects) }\end{array}$ & $\begin{array}{l}\text { - Multidisciplinary design teams share } \\
\text { and develop their expertise to } \\
\text { achieve a "socially shared mutual } \\
\text { target" } \\
\text { - Design teams create new } \\
\text { information together with the } \\
\text { teacher, client and other } \\
\text { stakeholders } \\
\text { - Creating information and working on } \\
\text { a mutual goal are completed in } \\
\text { interaction with the social } \\
\text { community through different tools } \\
\end{array}$ \\
\hline $\begin{array}{l}\text { 4. Assess- } \\
\text { ment of the } \\
\text { learning } \\
\text { exercise }\end{array}$ & $\begin{array}{l}\text { - Students receive a grade } \\
\text { based on the } \\
\text { development of their } \\
\text { competence }\end{array}$ & $\begin{array}{l}\text { - Students receive a grade } \\
\text { based on the development of } \\
\text { their competence } \\
\text { - In addition, students peer } \\
\text { review the results achieved by } \\
\text { their own team and other } \\
\text { teams }\end{array}$ & $\begin{array}{l}\text { - Students reflect on the learning of } \\
\text { their own group from the } \\
\text { perspective of mutually defined } \\
\text { learning objectives } \\
\text { - Students also peer review the } \\
\text { results achieved by other teams }\end{array}$ \\
\hline
\end{tabular}


The three metaphors of learning provide a useful framework of reference and conceptual tools for planning and evaluating pedagogical solutions. The pedagogical solutions of the three Master's courses we examined in their framework proved to be appropriate and well-justified. In addition, the study strengthened our ideas on organising, planning and implementing the activities of degree programmes, which should consider the continuity of different learning situations both during and between courses. The results of our study also indicate that the learning process of an innovative knowledge community should consist of all pedagogical solutions that support the different metaphors of learning and that should already be considered during the planning phase of the study unit. The three metaphors of learning and the three approaches based on them help to build appropriately progressive learning modules and diverse learning experiences. We have developed a tool presented in the table above (Table 2) for the design and evaluation of pedagogical solutions of study units and learning modules.

\section{ACKNOWLEDGEMENTS}

This study was conducted in the context of the Finnish Design Academy (FDA) project (2018 - 2020) that is one of the lead projects for developing university level design education, funded by the Finnish Ministry of Education and Culture and it supports the academic vision 2030 implementation.

This article is based on the text "Luojus, S., Tossavainen, P. \& Kauppinen, S. (2020) Pedagogisten ratkaisujen arvioinnin viitekehys: Kokemuksia Laurean palvelumuotoilun YAMK-opetuksesta" published in "Känkäinen, A. (edit.) 2020. Muotoiluala muutoksessa. Näkökulmia muotoiluosaamisen ja muotoilualan koulutukseen." Lahti; LAB-ammattikorkeakoulun julkaisusarja.

\section{REFERENCES}

[1] Paavola, S. \& Hakkarainen, K. 2008. Välittyneisyys ja trialogisuus innovatiivisten tietoyhteisöjen perustana. In: R. Engeström \& J. Virkkunen (edit.). Kulttuurinen välittyneisyys oppimisessa ja toiminnassa. Helsinki: University of Helsinki, Center for Activity Theory and Developmental Work Research. Tutkimusraportteja 11. 47-80.

[2] World Bank Open Data. 2020. Services, value added (\% of GPD). [Referenced on 09/10/2020]. Available at: https://data.worldbank.org/indicator/NV.SRV.TOTL.ZSA.

[3] Statistics Finland. 2020. Kansantalous. [Referenced on 09/10/2020]. Available at: https://www.tilastokeskus.fi/tup/suoluk/suoluk_kansantalous.html

[4] Kaupunkitutkimus TA Oy (edit.) 2020. Helsingin alue. Helsinki: Helsinki Region Chamber of Commerce. [Referenced on 15 November 2020]. Available at:

http://www.kaupunkitutkimusta.fi/toimialakatsaukset/helsingin-seudun-toimialakatsaus/

[5] Paavola, S. \& Hakkarainen, K. 2005. The Knowledge Creation Metaphor - An Epistemological Approach to Learning. Science \& Education 14(6), 535-557. Edinburgh, UK; Springer.

[6] Hakkarainen, K., \& Paavola, S. (2007). From monological and dialogical to trialogical approaches to learning. Paper presented at the international workshop "Guided Construction of Knowledge in Classrooms". Available at: http://escalate.org.il/construction_knowledge/papers/hakkarainen.pdf.

[7] Paavola, S., Hakkarainen, K., \& Seitamaa-Hakkarainen, P. 2006. Tutkivan oppimisen periaatteita ja käytäntöjä: "trialoginen" tiedonluomisen malli. In: S. Järvelä, P. Häkkinen, \& E. Lehtinen (edit.). Oppimisen teoria ja teknologian opetuskäyttö. Helsinki: WSOY. 147- 166.

[8] Sfard, A. 1998. On two metaphors for learning and the dangers of choosing just one. Educational Researcher. Vol. 27(2):4, 4-13.

[9] Raij, K. (edit.). 2014. LEARNING BY DEVELOPING ACTION MODEL. Vantaa: Laureaammattikorkeakoulu. Laurea Julkaisut 36.

[10] Paavola, S. 2012. Trialoginen oppiminen. In: Ilomäki, L. (edit.). Laatua e-oppimateriaaleihin. Eoppimateriaalit opetuksessa ja oppimisessa. Helsinki: Finnish National Agency for Education. Oppaat ja käsikirjat 2012:5. 115-120.

[11] Kauppinen S. \& Luojus S. 2020. Work-Oriented Project Learning in the Context of Master's Level Service Design Education. Gomez C., Lopez M., Candel T. (edit.). EDULEARN20 Proceedings. International Association of Technology, Education and Development. 